\title{
EXTRATO DE ALHO E ÓLEO VEGETAL NO CONTROLE DO MÍLDIO DA VIDEIRA ${ }^{1}$
}

\author{
CARLA DAIANE LEITE ${ }^{2}$, RENATO VASCONCELOS BOTELHO ${ }^{3}$, \\ CACILDA MARCIA DUARTE RIOS FARIA ${ }^{4}$, ALINE JOSÉ MAIA ${ }^{5}$
}

RESUMO - O objetivo deste trabalho foi verificar o efeito do extrato de alho e do óleo vegetal no controle do míldio da videira cv. Isabel (Vitis labrusca). A severidade da doença, expressa pela área abaixo da curva de progresso da doença (AACPD), e a germinação de esporângios de seu agente causal Plasmopara viticola foram as variáveis avaliadas. Os tratamentos consistiram em $0 ; 5 ; 10 ; 15 ; 20 ; 25$ ou $30 \mathrm{~mL} \mathrm{~L}^{-1}$ de extrato de alho adicionados de $2,5 \mathrm{~mL} \mathrm{~L}^{-1}$ óleo vegetal, calda bordalesa (1:1:100) e testemunha (sem tratamento). No teste de germinação, utilizou-se mancozebe $\left(2 \mathrm{~g} \mathrm{~L}^{-1}\right)$ como tratamento-padrão. Em condições de campo, observou-se redução da severidade do míldio com o óleo vegetal, sendo que o extrato de alho, a partir de $20 \mathrm{~mL} \mathrm{~L}^{-1}$, potencializou tal ação biocida. A germinação dos esporângios de $P$. viticola variou em função do tempo de exposição ao extrato de alho, não apresentando boa eficiência quando comparada ao tratamento com calda bordalesa e mancozebe. O óleo vegetal não influenciou na germinação dos esporângios desse patógeno. Termos para indexação: Vitis labrusca, Plasmopara viticola, controle alternativo.

\section{GARLIC EXTRACT AND VEGETABLE OIL IN THE CONTROL OF DOWNY MILDEW IN GRAPEVINES}

\begin{abstract}
The objective of this study was to verify the effect of garlic extract and vegetable oil in the control of downy mildew cv. Isabel (Vitis labrusca). Disease severity expressed as area under disease progress curve (AUDPC) and germination of the sporangia of its causal agent Plasmopara viticola were evaluated. The treatments tested consisted of $0 ; 5,10,15,20,25$ or $30 \mathrm{~mL} \mathrm{~L}^{-1}$ of garlic extract added to $2.5 \mathrm{~mL} \mathrm{~L}^{-1}$ of vegetable oil, bordeaux mixture $(1: 1: 100)$ and control. Mancozeb $\left(2 \mathrm{~g} \mathrm{~L}^{-1}\right)$ was used as a standard treatment in the germination test. In field conditions, there was reduction in severity of mildew with vegetable oil, and garlic extract from $20 \mathrm{~mL} \mathrm{~L}^{-1}$ potentiated such biocide action. The sporangium germination of P. viticola varied depending on the length of exposure to garlic extract, showing no efficient when compared to treatment with bordeaux mixture and mancozeb. Vegetable oil had no effect on sporangium germination of this pathogen. Index terms: Vitis labrusca, Plasmopara viticola, alternative control.
\end{abstract}

\section{INTRODUÇÃO}

O míldio da videira, doença causada por Plasmopara viticola (BERKELEY \& M. A. CURTIS) Berlese \& De Toni, é responsável pelos maiores danos na vitivinicultura no Sul do Brasil, assim como em outras regiões vitícolas do mundo. O prejuízo ocasionado por essa doença pode atingir até $75 \%$ da produção de uva, quando as condições climáticas são favoráveis (AMORIM; KUNIYUKI, 2005), e a severidade, elevada.

O controle químico deste patógeno na região sulina brasileira pode exigir de oito a 10 pulverizações com fungicidas (MENDES, 2002). Sabe-se que a solubilidade destes produtos químicos, associada a sua ação sistêmica são os principais fatores de risco para a contaminação dos subprodutos da uva (ROSE et al., 2009), sendo frequentemente encontrado no mosto de uva e no vinho (CABRAS; ANGIONI, 2000). Além disso, a adoção contínua de fungicidas sistêmicos pode acarretar na seleção de fitopatógenos resistentes (GHINI; KIMATI, 2000).

Frente a esses problemas, é necessário o desenvolvimento de novas tecnologias para atender a uma agricultura sustentável, visando, entre diversos fatores, ao controle de fitopatógenos com menor impacto ambiental. Neste sentido, substâncias extraídas de vegetais têm efeitos danosos ao desenvolvimento desses microrganismos (COUTINHO et al., 1999). Entre tais substâncias, destaca-se o alho (Allium

'(Trabalho 133-10). Recebido em: 26-05-2010. Aceito para publicação em: 05-04-2011. Parte da dissertação de mestrado do primeiro autor ${ }^{2}$ Eng $^{\mathrm{a}}$. Agr ${ }^{\mathrm{a}}$. MSc. Dept ${ }^{\circ}$. de Agronomia da Universidade Estadual do Centro Oeste - UNICENTRO. Guarapuava-PR, 85040-080. Email: cdaianeleite@hotmail.com

${ }^{3}$ Eng. Agr. Dr. Prof. Adjunto do Dept ${ }^{\circ}$. de Agronomia da Universidade Estadual do Centro Oeste - UNICENTRO, Setor Fruticultura. Bolsistas de Produtividade CNPq. E-mail:rbotelho@unicentro.br*Autor para correspondência.

${ }^{4} E_{n g}$. Agra ${ }^{a}$. Dr. Prof. Adjunto do Dept ${ }^{\circ}$. de Agronomia da Universidade Estadual do Centro Oeste UNICENTRO, Setor Fitopatologia. E-mail: cfaria@unicentro.br

${ }^{5}$ Eng $^{\mathrm{a}}$. Agr ${ }^{\mathrm{a}}$. MSc. Dept ${ }^{\mathrm{o}}$. de Agronomia da Universidade Estadual do Centro Oeste - UNICENTRO. Email:alymaia2005@yahoo.com 
sativum L.), que, por meio do emprego de seus óleos e extratos, pode atuar in vitro contra fungos de frutíferas, como Colletotrichum gloeosporioides (RIBEIRO; BEDENDO, 1999), Elsinoe ampelina (BOTELHO et al. 2009) e Botrytis cinerea (CURTIS et al., 2004). O extrato de alho também apresenta atividade fungitóxica e/ou fungistática na germinação do oomiceto Phytophthora infestans, com redução da severidade da doença em tomateiro (CURTIS et al., 2004; PORTZ et al., 2008), não havendo relato sobre o oomiceto $P$. viticola em videira.

Outro produto de origem vegetal com ação fitossanitária são óleos extraídos de sementes de plantas (CORRÊA, 2005). Steinhauer (1999) constatou que extrato aquoso de sementes de nim inibiram fortemente a produção de esporângios de P. viticola em folhas de videira destacadas. Outro relato foi aquele observado por Junqueira (2004) ao utilizar o óleo de soja no controle da antracnose em pós-colheita de manga.

Neste contexto, o objetivo deste trabalho foi verificar o efeito do extrato de alho e do óleo vegetal sobre o míldio da videira em condições de campo, na cv. Isabel, e na germinação de esporângios de $P$. viticola.

\section{MATERIAL E MÉTODOS}

Os experimentos foram conduzidos no Laboratório de Fitopatologia do Departamento de Agronomia da Universidade Estadual do CentroOeste (UNICENTRO) e em vinhedo comercial, em Guarapuava-PR.

\section{Obtenção do extrato de alho (EA)}

Para a obtenção do EA, utilizou-se alho adquirido comercialmente na região de Guarapuava junto a um produtor orgânico. Os bulbilhos foram triturados em extratora de sucos tipo centrífuga doméstica com posterior filtragem em papel-filtro, no mesmo dia da sua utilização, com rendimento na proporção $3: 1(\mathrm{p} / \mathrm{v})$. Durante a condução dos experimentos, o alho permaneceu em local arejado, à sombra, em temperatura ambiente.

Efeito do extrato de alho no controle do míldio em videiras cv. Isabel

O experimento foi instalado em Guarapuava-PR (latitude de $25^{\circ} 23^{\prime} 36^{\prime \prime} \mathrm{S}$, longitude de $51^{\circ} 27^{\prime} 19$ "O e altitude de $1.120 \mathrm{~m}$ ), em vinhedo comercial de videiras cv. Isabel (Vitis labrusca), enxertadas sobre 'Paulsen 1103' (V. rupestris $\mathrm{x}$ $V$. berlandieri) com um ano de idade, conduzidas em espaldeira, espaçadas $2,5 \times 2,0 \mathrm{~m}$ e em sistema orgânico. O solo no qual o vinhedo está implantado é classificado como Latossolo bruno distroférrico típico textura muito argilosa.

Os tratamentos consistiram no extrato de alho nas doses de $0 ; 5 ; 10 ; 15 ; 20 ; 25$ ou $30 \mathrm{~mL} \mathrm{~L}^{-1}$ acrescidas de $2,5 \mathrm{~mL} \mathrm{~L}^{-1}$ de óleo vegetal $\left(930 \mathrm{~mL} \mathrm{~L}^{-1}\right.$ óleo de soja, Natur'1 óleo $^{\circledR}$, Stoller) e calda bordalesa na proporção de 1:1:100 (sulfato de cobre:cal virgem:água), além de uma testemunha absoluta sem tratamento. Neste experimento, não se empregou o tratamento-padrão (químico), porque se tratava de um vinhedo orgânico, onde o uso de substâncias sintéticas é vetada.

Após a poda de inverno, em 9 de setembro de 2008, realizaram-se as pulverizações a cada 15 dias ou após o acúmulo de $30 \mathrm{~mm}$ de precipitação, totalizando 15 aplicações. As aplicações foram realizadas até o ponto de escorrimento (1litro/planta), com auxílio de pulverizador manual com um bico do tipo cone cheio, sempre após as 17 horas.

Com o aparecimento dos primeiros sintomas do míldio da videira, verificados a partir de 28 de novembro de 2008, realizaram-se quatro avaliações semanais consecutivas da severidade da doença com o auxílio de escala diagramática proposta por Azevedo (1997), em três folhas do ápice de três ramos por planta, previamente identificadas. Com os dados da severidade, foi determinada a área abaixo da curva de progresso da doença (AACPD), proposta por Shaner e Funney (1977). Durante a execução do experimento, no período de 28-09-08 a 01-01-09, monitoraram-se a temperatura, a precipitação fluvial e a umidade relativa do vinhedo.

$\mathrm{O}$ delineamento experimental foi em blocos ao acaso, com nove tratamentos, cinco repetições e parcela experimental constituída por uma planta. Os dados foram submetidos à análise da variância e, quando significativa, estudaram-se a regressão polinomial e a comparação de médias dos tratamentos, doses, calda bordalesa e testemunha, pelo teste de Tukey $(\mathrm{P} \leq 0,05)$, por meio do programa estatístico SISVAR (FERREIRA, 2008), com dados transfor$\operatorname{mados} \sqrt{x+1}$.

Efeito do extrato de alho na germinação de esporângios de Plasmopara viticola

Os tratamentos avaliados foram os mesmos do ensaio anterior acrescidos do tratamento químico de $2 \mathrm{~g} \mathrm{~L}^{-1}$ de mancozebe (Manzate ${ }^{\circledR} 800$ PM, Dow AgroSceinces Industrial LTDA) e de tratamento sem óleo vegetal $(\mathrm{OV})$.

Adicionaram-se $100 \mathrm{~mL}$ de água destilada esterilizada com Tween $80(0,5 \%)$ sobre folhas de videira com sintomas típicos do míldio da videira e, com o auxílio de uma alça de Drigalski, esfregou-se o micélio fúngico, com posterior filtragem em duas camadas de gaze esterilizada. A suspensão obtida foi 
calibrada em câmara de Neubawer (hemocitômetro) para 2,2 x $10^{6}$ esporângios $\mathrm{mL}^{-1}$.

Alíquotas de $40 \mu \mathrm{L}$ da suspensão de esporângios e de $40 \mu \mathrm{L}$ da solução de cada um dos tratamentos foram colocadas em cavidades individuais de placas de teste Elisa (REGENTE et al., 1997).

Em seguida, essas placas foram mantidas em câmara de crescimento a $20^{\circ} \mathrm{C}$, no escuro, durante 6 e 12 horas. Para cada período, a germinação dos esporângios foi paralisada com a adição de $20 \mu \mathrm{L}$ do corante lactofenol-azul de algodão. Avaliou-se a porcentagem de germinação de forma aleatória em lâminas, no microscópio óptico, totalizando 100 esporângios, em quatro repetições. Foram considerados germinados aqueles que apresentavam liberação dos zoósporos. Este experimento foi repetido duas vezes.

O delineamento experimental utilizado foi inteiramente casualizado, com 10 tratamentos e quatro repetições. Os dados foram submetidos à análise da variância e, quando significativo, aplicaram-se regressão polinomial para as doses e comparação de médias, pelo teste de Tukey $(\mathrm{P} \leq 0,05)$, de todos os tratamentos, através do programa estatístico SISVAR (FERREIRA, 2008).

\section{RESULTADOS E DISCUSSÃO}

Durante a condução do experimento no vinhedo, observaram-se condições climáticas favoráveis (temperatura amena associada à umidade relativa alta) para o desenvolvimento do míldio da videira (BEDENDO, 1995), principalmente no período que antecede a infecção inicial. Constataram-se temperatura acumulada entre 18 a $25^{\circ} \mathrm{C}$, umidade relativa do ar entre 70 a $95 \%$ e precipitação acumulada de $639 \mathrm{~mm}$ (Figura 1).

No experimento a campo, notou-se efeito do $\mathrm{OV}$ associado ou não ao EA sobre a severidade do míldio da videira, expressa pela AACPD, sendo que o tratamento somente com OV reduziu em $52 \%$ esta área, em relação à testemunha absoluta (sem tratamento) (Figura 2). Existem poucos trabalhos em que a ação do óleo vegetal de soja foi avaliada isoladamente em doenças de frutíferas, caracterizando-o apenas por sua utilização como adjuvante e/ou inseticida (MENDONÇA et al., 2007).

Observou-se efeito quadrático das doses crescentes de EA e a AACPD do míldio, sendo que, a partir da dose $20 \mathrm{~mL} \mathrm{~L}^{-1}$ de extrato, constataram-se reduções de $62,94 \%$ e 75,43\%, em relação às plantas sem tratamento. Estas doses de EA foram estatisticamente similares ao tratamento-padrão com calda bordalesa
(Figura 2). Peruch e Bruna (2008) confirmaram a alta eficiência da calda bordalesa no controle do míldio da videira com redução de $98 \%$ da AACPD. Outra característica dessa calda, confirmada por Peruch et al. (2007), foi a redução da incidência desta doença; entretanto, segundo Garrido et al. (2004), produtos à base de cobre têm contribuído ao desequilíbrio do agroecossistema, pois acumulam-se no solo por longo tempo. E, segundo Diniz et al. (2006), ressaltam a fitotoxidade em plantas de videira em situações de uso prolongado desse fungicida.

Neste contexto, o extrato extraído de bulbilhos de alho poderá ser uma alternativa no controle do míldio da videira, com menores riscos de contaminação ambiental. Portz et al. (2008) constataram alta atividade antimicrobiana do alho, em especial da alicina, contra fitopatógenos como P. infestans, em mudas de tomateiro, e de Pseudoperonospora cubensis, em pepino, com redução dos sintomas de 45 a $100 \%$ e 50 a $100 \%$, respectivamente. Outras substâncias, presentes no alho, como ajoenos, tiossulfinatos e compostos organossulfurados, podem apresentar ação biocida (LEDEZMA; APITZ-CASTRO, 2006) ou na indução de resistência das plantas a patógenos, atribuída à alicina (ANTONIAZZI; DESCHAMPS, 2007).

Com relação ao efeito do EA na germinação de esporângios de $P$. viticola, o modelo quadrático foi o que melhor se ajustou aos dados dessa variável nos dois períodos de avaliações, em função do aumento das doses do extrato (Figura 3 e 4). No entanto, a redução da germinação dos esporângios, proporcionada pelo EA, foi, de maneira geral, significativamente menor do que aquela verificada para os tratamentos com calda bordalesa e mancozebe, que reduziram em $62,65 \%$ e $55,42 \%$ às 12 horas de imersão, respectivamente, em relação à dose de $30 \mathrm{~mL}^{-1}$ de extrato (Figura 3). Quando se avaliou o efeito do EA na germinação sem a presença do $\mathrm{OV}$, verificou-se o potencial fungitóxico do extrato 6 horas após a incubação, não diferindo estatisticamente dos tratamentos-padrão (calda bordalesa e mancozebe) (Figura 4). Na segunda avaliação (12 horas), observou-se perda de eficiência do extrato com o decorrer do tempo, não diferindo estatisticamente da concentração zero, ao contrário da calda bordalesa e do mancozebe (Figura 4). Estes resultados não são concordantes com aqueles obtidos por Ke-Qiang e Van Bruggen (2001), que verificaram inibição de $100 \%$ da germinação de zoósporos de $P$. infestans nas concentrações de $0,5 \%$; $1 \% ; 2 \% ; 4 \%$ e $8 \%$ de extrato de alho. Souza et al. (2007) constataram decréscimos nos percentuais de germinação dos esporos de Fusarium proliferatum 
após imersão por $6 ; 12 ; 18$ e 24 horas em extrato de alho, nas concentrações de 2,5\%; 5\% e 10\%. De modo similar, Wilson et al. (1997) apresentaram o potencial fungitóxico de diferentes espécies de Allium na germinação de $B$. cinerea após $24 \mathrm{e}$ 48 horas de imersão no extrato de alho. Também Morais (2004), empregando extratos aquosos, hidroalcoólios e etanólicos e óleos essenciais de alho, verificou efeito inibitório na germinação de F. oxysporum.

Na literatura, não há informações sobre a ação de óleos vegetais no controle de doenças foliares em videira; entretanto, neste trabalho, o óleo vegetal apresentou efeito sobre a severidade do míldio em condições de campo. Carneiro et al. (2007) constataram controle do oídio (Erysiphe polygoni) em folhas de feijão tratadas com $0,25 \%$ a $2 \%$ de produtos à base de nim antes e após o aparecimento dos sintomas da doença. Controle pós-colheita da antracnose (Colletotrichum gloeosporioides) em manga foi observado com a imersão dos frutos em óleo de soja (JUNQUEIRA et al., 2004).

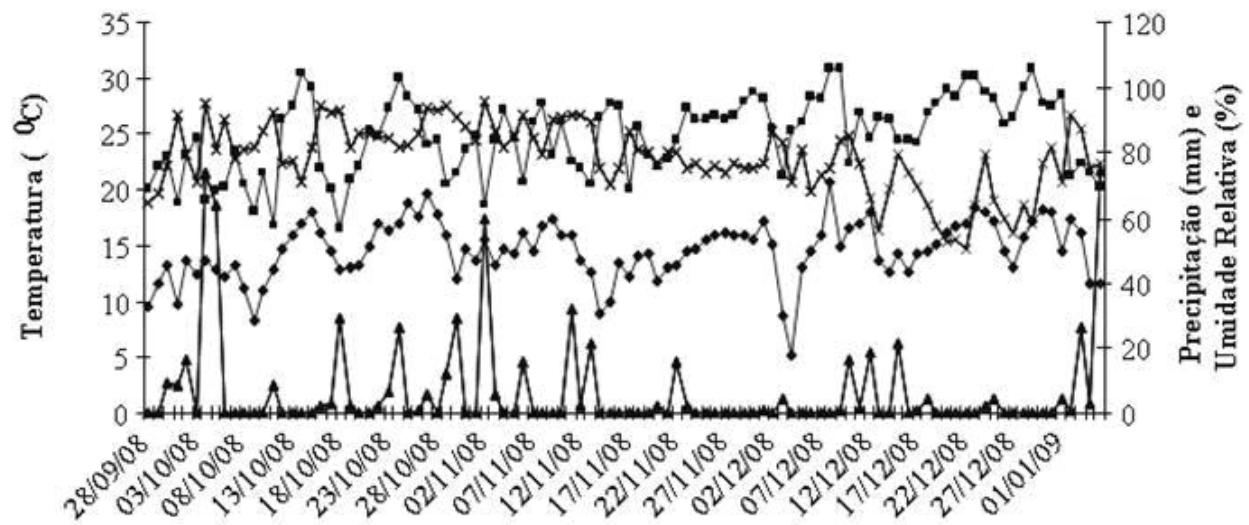

Periodo Experimental

$\rightarrow$ Temp $\max \left({ }^{\circ} \mathrm{C}\right) \rightarrow$ Temp $\min \left({ }^{\circ} \mathrm{C}\right) \rightarrow$ Precip. $(\mathrm{mm}) \rightarrow$ UR $(\%)$

FIGURA 1-Temperaturas, precipitação pluviométrica, umidade relativa mensuradas entre os dias 28-09-08 a 01-01-09, no município de Guarapuava - PR.

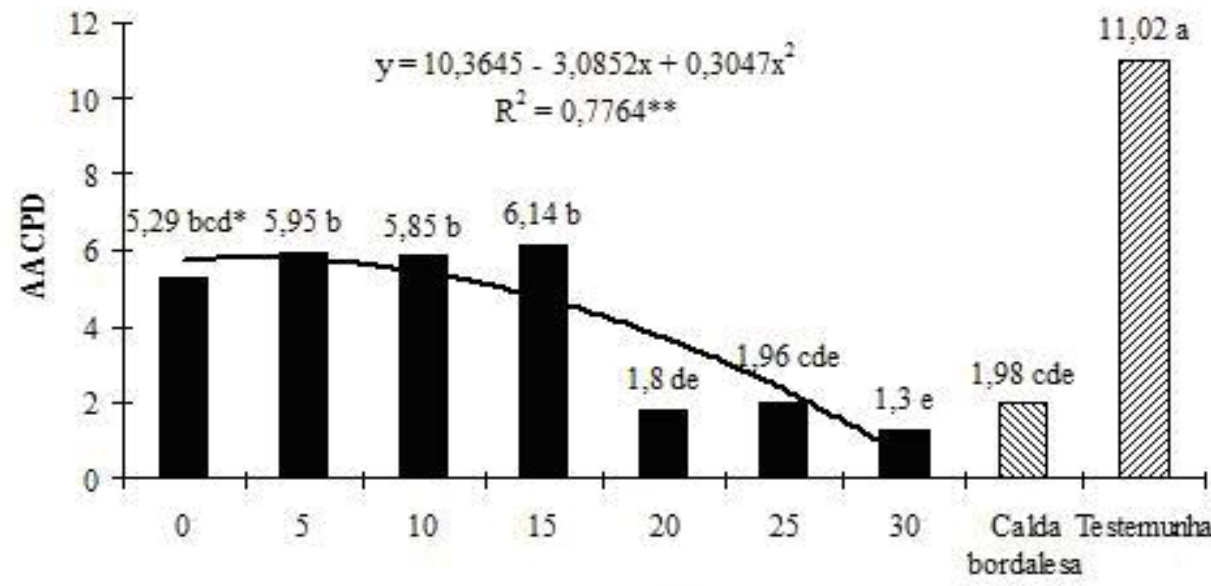

Extrato de alho $\left(\mathrm{mL} \mathrm{L}^{-1}\right)$

FIGURA 2 - Área abaixo da curva do progresso da doença (AACPD) obtido a partir de quatro avaliações de severidade de míldio (Plasmopara viticola) em videira cv. Isabel, pulverizadas com diferentes doses de extrato de alho $+2,5 \mathrm{~mL} \mathrm{~L}^{-1}$ de óleo vegetal, calda bordalesa e testemunha (sem tratamento) (Guarapuava-PR)

*Médias seguidas de letras distintas diferem pelo teste de Tukey $(\mathrm{P}<0,05)$. **Regressão polinominal significativa a $5 \%$ de probabilidade (Dados transformados $\sqrt{x+1}$ ). 


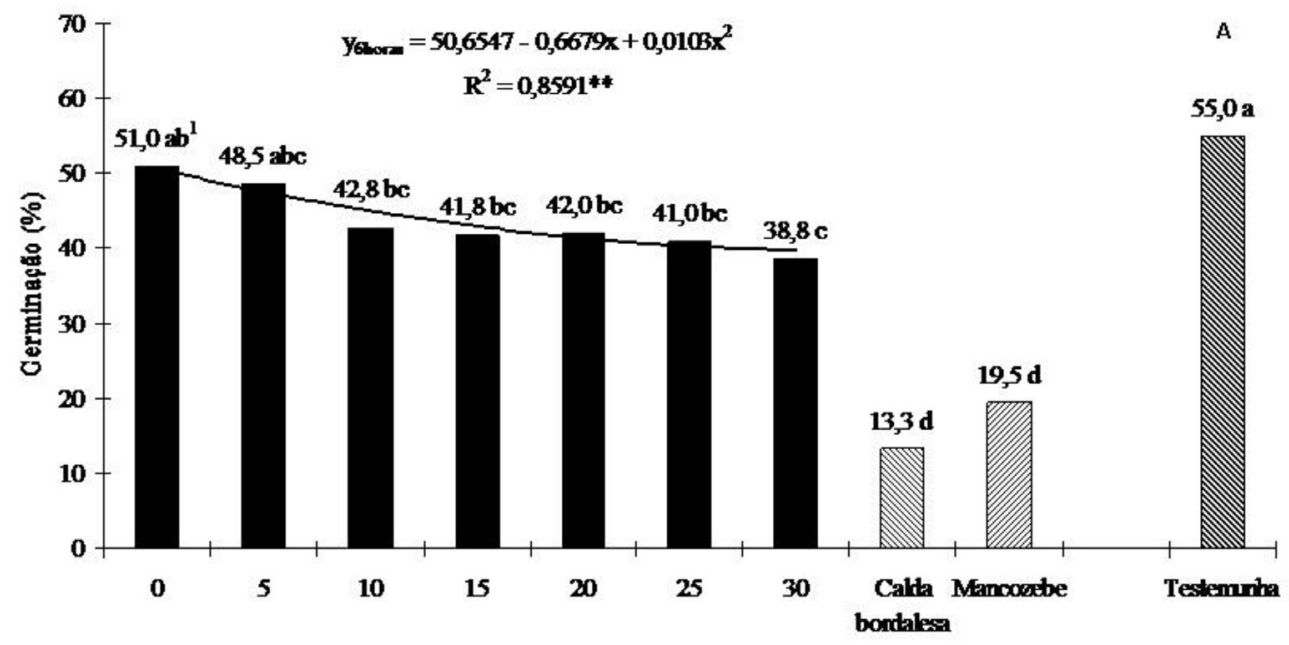

Extrato de alho (-L.')

B

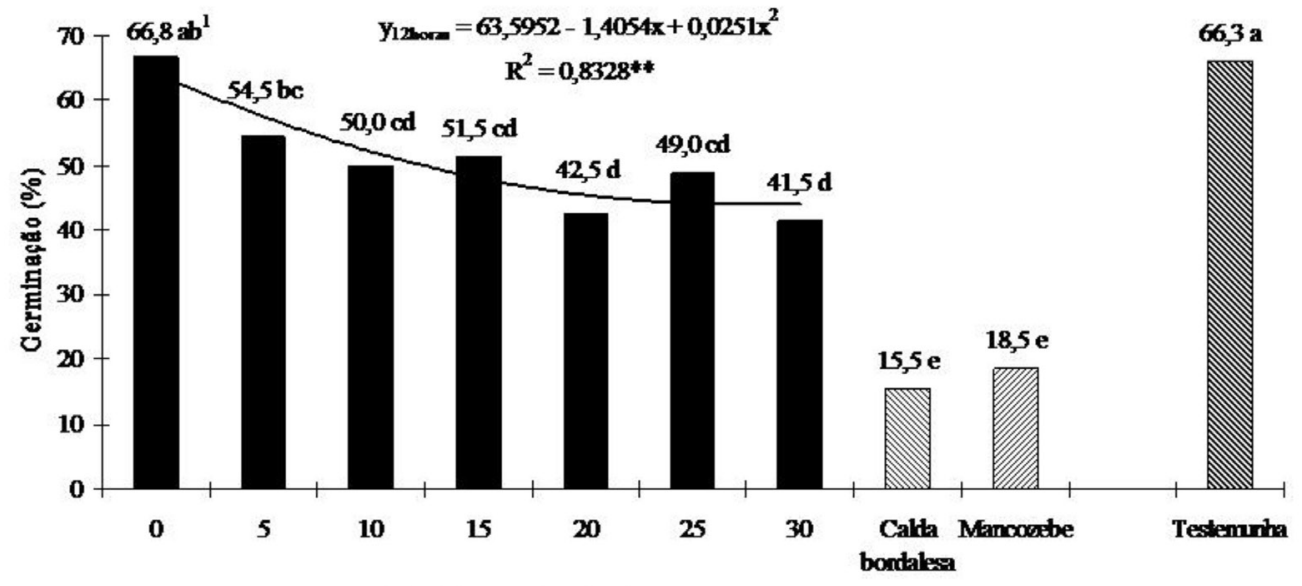

Extrito de alho (1.L.L)

FIGURA 3 - Germinação de esporângios de Plasmopara viticola imersos em extrato de alho (diferentes doses) com óleo vegetal $\left(2,5 \mathrm{~mL} \mathrm{~L}^{-1}\right)$, calda bordalesa, mancozebe, testemunha (sem tratamento) durante 6 horas (A) e 12 horas (B).

${ }^{1}$ Médias seguidas de letras distintas diferem pelo teste de Tukey $(\mathrm{P} \leq 0,05)$. **Regressão polinominal significativa a $5 \%$ de probabilidade. 


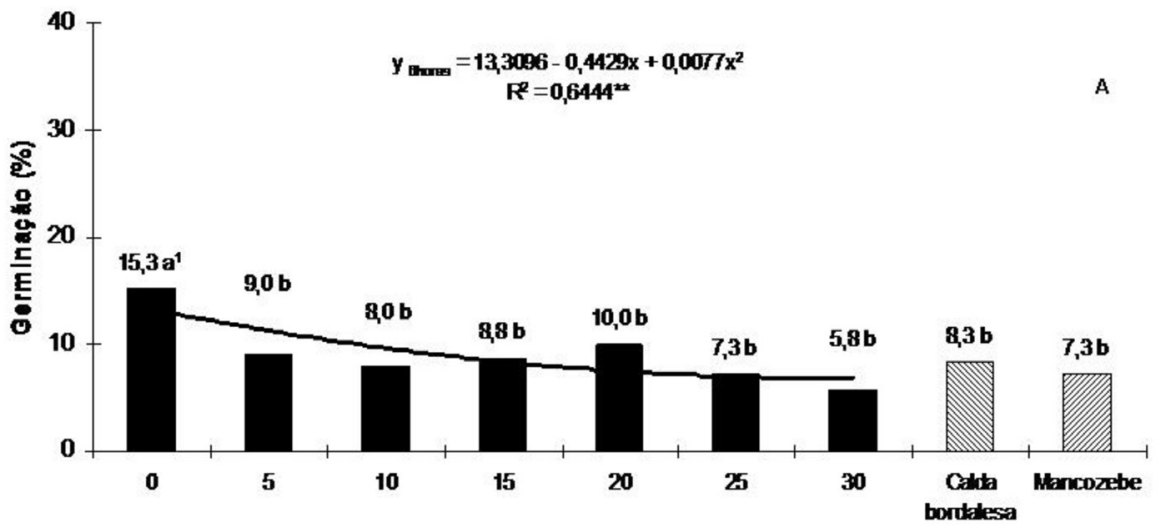

Extrato de alho (mL L-1)

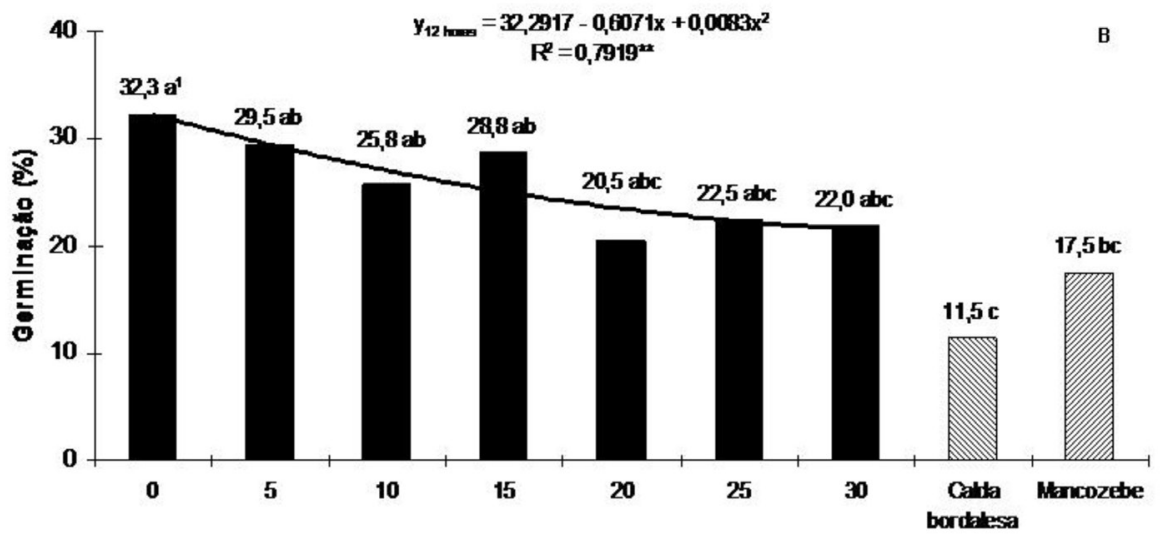

Extrato de alho (mL L-1)

FIGURA 4- Germinação de Plasmopara viticola imersos em extrato de alho (diferentes doses) sem óleo vegetal, calda bordalesa, mancozebe e testemunha (sem tratamento) durante 6 horas (A) e 12 horas (B).

${ }^{1}$ Médias seguidas de letras distintas diferem pelo teste de Tukey $(\mathrm{P} \leq 0,05) . * *$ Regressão polinominal significativa a 5\% de probabilidade.

\section{CONCLUSÃO}

1-O óleo vegetal, isolado ou misturado com o extrato de alho, reduz a severidade do míldio da videira.

2-A germinação de esporângios de Plasmopara viticola foi afetada pela presença do óleo vegetal quando misturado ao extrato de alho.

3-Nas condições em que este trabalho foi desenvolvido, o extrato de alho e o óleo vegetal apresentaram grande potencial de utilização no controle do míldio da videira, principalmente em vinhedos orgânicos, podendo ser alternado com a calda bordalesa.

\section{AGRADECIMENTOS}

Ao Sr. Lauri Leite, pela concessão da área de vinhedo orgânico, e à Fundação Araucária/SETI, pela bolsa concedida ao primeiro autor.

\section{REFERÊNCIAS}

AMORIM, L.; KUNIYUKI, H. Doenças da videira. In: KIMATI, H.; AMORIM, L.; REZENDE, J.A.M.; BERGAMIN FILHO, A.; CAMARGO, L.E.A. Manual de fitopatologia: doenças das plantas cultivadas. 4.ed, São Paulo: Agronômica Ceres, 2005. v.2, p.639-651. 
ANTONIAZZI, N.; DESCHAMPS, C. Controle de Bipolaris sorokiniana e rendimento de grãos de cevada após aplicação de elicitores e fungicida. Acta Sciense Agronomic, Maringá, v.29 supl., p. 695-700, 2007. Disponível em: <http://periodicos.uem.br/ojs/ index.php/ActaSciAgron/article/viewArticle/749>. Acesso em: 04 fev. 2010.

AZEVEDO, L.A. Manual de quantificação de doenças de plantas. São Paulo: Luiz Azevedo, 1997. p.51-102.

BEDENDO, I. P. Míldios. In: BERGAMIN FILHO, A.; KIMATI, H.; AMORIM, L. Manual de fitopatologia. 3. ed. São Paulo: Agronômica Ceres, 1995. $2 \mathrm{v}, 919 \mathrm{p}$.

BOTELHO, R.V.; MAIA, A.J.; PIRES, E.J.P.; TERRA, M.M. Efeito do extrato de alho na quebra de dormência de gemas de videiras e no controle in vitro do agente causal da antracnose (Elsinoe ampelina Shear). Revista Brasileira de Fruticultura, Jaboticabal, v.31, n.1, p.096-102, 2009. Disponível em: <http://www.scielo.br/scielo.php?script=sci_ar ttext\&pid=S0100-29452009000100015>. Acesso em: 28 nov. 2009.

CABRAS, P.; ANGIONI, A. Pesticide residues in grapes, wine and their processing products. Journal of Agriculture and Food Chemistry, Easton, v.48, n.4, p.967-973, 2000.

CARNEIRO, S.M. DE T.P.G.; PIGNONI, E.; VASCONCELLOS, M.E. DA C.; GOMES, J.C. Eficácia de extratos de nim para o controle do oídio do feijoeiro. Summa Phytopathologica, Botucatu, v.33, n.1, p.34-39, 2007. Disponível em: <http://www.scielo. br/pdf/sp/v33n1/05.pdf>. Acesso em: 22 out. 2010.

CORREAA, C.M.D. Efeito do óleo de soja na persistência de endosulfan no ambiente. 2005. 102 f. Tese (Doutorado em Ecologia do Ecossistema) Escola Superior de Agricultura "Luiz de Queiroz", Universidade de São Paulo, Piracicaba, 2005.

COUTINHO, W.M.; ARAÚJO, E.; MAGALHÃES, F.H.L. Efeitos de extratos de plantas anacardiáceas e dos fungicidas químicos benomyl e captan sobre a microflora e qualidade fisiológica de feijoeiro (Phaseolus vulgaris L.). Ciência e Agrotecnologia, Lavras, v.23, n. 3, p.560-568, 1999. Disponível em: $<$ http://www.editora.ufla.br/revista/23_3/art09.pdf $>$. Acesso em: 15 jun. 2009.
CURTIS, H.; NOLL, U.; STORMANN, J.; SLUSARENKO, A.J. Broad-spectrum activity of the volatile phytoanticipin allicin in extracts of garlic (Allium sativum L.) against plant pathogenic bacteria, fungi and Oomycetes. Physiological and Molecular Plant Pathology, London, v.65, p.79-89, 2004. Disponível em: $<$ http://www.sciencedirect.com/science $>$. Acesso em: 28 nov. 2009.

DINIZ, L.P.; MAFFIA, L.A.; DHINGRA, O.D.; CASALI, V.W.D.; SANTOS, R.H.S.; MIZUBUTI, E.S.G. Avaliação de produtos alternativos para controle da requeima do tomateiro. Fitopatologia Brasileira, Brasília, v.31, n 2, p.171-179, 2006. Disponível em: <http://www.scielo.br/pdf/fb/v31n2/30011.pdf $>$. Acesso em: 10 jan. 2010.

FERREIRA, D.F. SISVAR: um programa para análises e ensino de estatística. Revista Symposium, Recife, v.6, p.36-41, 2008.

GARRIDO, L.R.; SÔNEGO, O.R.; VALDEBENITO-SANCHUEZA, R.M. Controle racional de doenças da videira e da macieira. In: STADNIK, M.J; TALAMINI, V. Manejo ecológico de doenças de plantas. Florianópolis: CCA/UFSC, 2004. p.221-244

GHINI, R.; KIMATI, H. Resistência de fungos a fungicidas. Jaguariúna: Embrapa Meio Ambiente, 2000. 78 p.

KE-QIANG, C.; VAN BRUGGEN, A.H.C. Inhibitory efficacy of several plant extracts and plant products on Phytophthora infestans. Journal of Agricultural University of Hebei, Baoding, v.24, p.108-116, 2001.

JUNQUEIRA, N.T.V.; CHAVES, R.C.; NASCIMENTO, A.C.; RAMOS, V.H.V.; PEIXOTO, J.R.; JUNQUEIRA, L.P. Efeito do óleo de soja no controle da antracnose e na conservação da manga cv. Palmer em pós-colheita. Revista Brasileira de Fruticultura, Jaboticabal, v.26, n.2, p.222-225, 2004. Disponível em: <http://www.scielo.br/pdf/rbf/ v26n2/21811.pdf >. Acesso em: 15 jan. 2010.

LEDEZMA, E.; APITZ-CASTRO, R. Ajoene, el principal compuesto activo derivado del ajo (Allium sativum), un nuevo agente antifúngico. Revista Iberoamericana de Micologia, v.23. p.75-80, 2006. Disponível em: $<$ http://www.reviberoammicol. com/2006-23/075080.pdf $>$. Acesso em: 28 nov. 2009 . 
MENDES, C.S. Flutuação de inóculo no ar, desenvolvimento e validação de um sistema de previsão do míldio da videira. 2002. 123 f. Dissertação (Mestrado em Fitopatologia) - Universidade de Passo Fundo, Passo Fundo, 2001.

MENDONÇA, C.G. DE; RAETANO, C.G.; MENDONÇA, C.G. DE. Tensão superficial estática de soluções aquosas com óleos minerais e vegetais utilizados na agricultura. Engenharia Agrícola, Jaboticabal, v.27, p.16-23, 2007. Disponível em: $<$ http://www.scielo.br/pdf/eagri/v27nspe/03.pdf $>$. Acesso em: 24 out. 2010.

MORAIS, M.H.D. Análise sanitária de sementes tratadas. In: SIMPÓSIO BRASILEIRO DE PATOLOGIA DE SEMENTES, 8., 2004, João Pessoa. Resumos... p.12-12.

PERUCH, L.A.M.; BRUNA, E.D. Relação entre doses de calda bordalesa e de fosfito potássico na intensidade do míldio e na produtividade da videira cv. 'Goethe'. Ciência Rural, Santa Maria, v.38, n.9, p.2413-2418, 2008. Disponível em: $<$ http://www.scielo.br/scielo.php?pid=S0103$84782008000900001 \&$ script $=$ sci_arttext $>$. Acesso em: 16 maio 2009.

PERUCH, L.A.M.; MEDEIROS, A.M.; BRUNA, E.D.; STADINIK, M. Biomassa cítrica, extrato de alga, calda bordalesa e fosfito no controle do míldio da videira, cv. Niágara Branca. Revista de Ciências Agroveterinárias, Lages, v.6, n.2, p.143-148, 2007. Disponível em: $<$ http://rca.cav.udesc.br/rca_2007_2/ peruch.pdf $>$. Acesso em: 16 maio 2009.

PORTZ, D.; KOCH, E.; SLUSARENKO, A.J. Effects of garlic (Allium sativum) juice containing allicin on Phytophthora infestans and downy mildew of cucumber caused by Pseudoperonospora cubensis. European Journal of Plant Pathology, Wageningen, v.122, p.197-206, 2008.
REGENTE, M.C.; OLIVA, C.R.; FELDMAN, M.L.; CASTAGNARO, A.P.; LACANAL, L. Sunflower leaf antifungal peptide active against Sclerotinia sclerotiorum. Physiologia Plantarum, Dordrecht, v.100, n.1, p.178-182, 1997

RIBEIRO, L.F.; BEDENDO, I.P. Efeito inibitório de extratos vegetais sobre Colletotrichum gloeosporioides - agente causal da podridão de frutos de mamoeiro. Scientia Agricola, v.56, n.4, supl., p.1267-1271, 1999. Disponível em: <http://www.scielo.br/pdf/sa/ v56n4s0/a31v564s.pdf $>$. Acesso em: 15 jan. 2010.

ROSE, G.; LANE, S.; JORDAN, R. The fate of fungicide and insecticide residues in Australian wine grape by-products following field application. Food Chemistry, Kidlington, v.117, n.4, p.634-640, 2009. Disponível em: <www.elsevier.com/locate/ foodchem>. Acesso em: 20 nov. 2010.

SHANER, G.; FINNEY, R. The effect of nitrogen fertilization on the expression of slow mildewing resistance in Knox Wheat. Journal of Phytopathology, Saint Paul, v.67, n.8, p.1051-1056, 1977.

SOUZA, A.E.F.; ARAÚJO, E.; NASCIMENTO, L.C. Atividade antifúngica de extratos de alho e capim-santo sobre o desenvolvimento de Fusarium proliferatum isolado de grãos de milho. Fitopatologia Brasileira, Brasília, v.32, n.6, p.465-471, 2007. Disponível em: <http://www.scielo.br/pdf/fb/v32n6/ a03v32n6.pdf $>$. Acesso em: 15 jan. 2010.

STEINHAUER, B. Possible ways of using the neem tree to control phytopathogenic fungi. Plant Research and Development, Hamburg, v.50, p.8392, 1999.

WILSON, C.L.; SOLAR, J.M.; GHAOUTH, A.E.; WINIEWSKI, M.E. Rapid evaluation of plant extracts and essential oils for antifungal activity against Botrytis cinerea. Plant Disease, Beltsville, v. 81 , n.2, p.204-210, 1997. Disponível em: $<$ http://www. apsnet.org/pd/PDFS/1997/0106-05R.PDF>. Acesso em: 15 jan. 2010. 